\title{
Lactose Intolerance: What Consumers Need to Know ${ }^{1}$
}

\author{
Matt Krug and Amy Simonne ${ }^{2}$
}

\section{What is lactose intolerance?}

Lactose malabsorption is a condition that occurs when people cannot effectively digest lactose (a unique carbohydrate in milk) because they are lacking the lactase enzyme to some degree. Lactose intolerance is defined as gastrointestinal symptoms that are displayed in an individual who is a lactose malabsorber after consumption of lactosecontaining products (Misselwitz et al. 2013). Undigested lactose molecules may collect inside the intestine and contribute to diarrhea. Lactose may also be fermented by gut microflora producing health-enhancing substances (i.e., short chain fatty acids) but also gases that may result in bloating and other possible symptoms such as abdominal pain, nausea, and flatulence (Di Rienzo et al. 2013).

A common cause of lactose malabsorption is lactase non-persistence, which is a condition where lactase activity is reduced in individuals after weaning. Lactase nonpersistence is often related to our age and genetic origin. While some populations usually see a decline in lactase activity after ages 2-3, other populations (mainly Northern European) often retain high lactase levels into adulthood (Misselwitz et al. 2013; Itan et al. 2010).

Managing lactose intolerance depends on the intensity and severity of symptoms. Treatments include reducing lactosecontaining foods (dairy), replacing lactose-containing foods with other foods containing similar nutrients, and using lactase supplements or similar products. This publication will provide information and guidance for consumers so that they may find the right information for their situation.

- Lactase non-persistence: in humans, when the expression of the enzyme lactase decreases after weaning

- Lactose maldigestion: ineffective digestion of lactose due to lactase non-persistence.

- Lactose intolerance: when an individual with lactose malabsorption displays gastrointestinal symptoms after consumption of lactose-containing products.

\section{What are my chances of having lactase non-persistence?}

While the percentage of the population affected with lactase non-persistence varies greatly between research studies, generally, less than $20 \%$ of Caucasians are affected. People of Hispanic, African-American, and Native American origin all tend to have a higher frequency of lactase nonpersistence, with an estimated $50 \%-80 \%$ of the population affected (Nicklas et al. 2011; Scrimshaw and Murray 1988). The Asian population has the highest occurrence. In some Asian countries, close to $100 \%$ of the population has lactase non-persistence (Lomer et al. 2007; Storhaug et al. 2017).

It is important to note that 1) many factors affect these estimated percentages, and they do not necessarily represent every country within each of these regions, and 2) having lactase non-persistence does not always mean that you will experience the symptoms of lactose intolerance.

1. This document is FSHN18-13, one of a series of the Food Science and Human Nutrition Department, UF/IFAS Extension. Original publication date November 2018. Visit the EDIS website at https://edis.ifas.ufl.edu for the currently supported version of this publication.

2. Matt Krug, state specialized agent, Food Science, UF/IFAS Southwest Florida Research and Education Center; and Amy Simonne, professor, Department of Family, Youth and Community Sciences; UF/IFAS Extension, Gainesville, FL 32611.

The Institute of Food and Agricultural Sciences (IFAS) is an Equal Opportunity Institution authorized to provide research, educational information and other services only to individuals and institutions that function with non-discrimination with respect to race, creed, color, religion, age, disability, sex, sexual orientation, marital status, national origin, political opinions or affiliations. For more information on obtaining other UF/IFAS Extension publications, contact your county's UF/IFAS Extension office. 


\section{What are the main sources of lactose in food?}

Milk and milk products are the primary sources of lactose. Many animals produce milk, but the amount of lactose in each variety varies substantially between species and due to nutritional, genetic, and environmental factors (Park, Haenlein, and Wendorff 2017). Common sources for milk intended for human consumption include cows, goats, sheep, and humans (for babies who are breastfed) (Table 1). In addition, other processed foods such as cream, cheese, butter, yogurt, cakes, and other milk-containing foods may also contain lactose. Fermented milk products and some cheeses may have reduced levels of lactose. Lactose levels of popular food products containing lactose are provided in Table 2.

Table 1. Primary sources of lactose.

\begin{tabular}{|l|c|}
\hline \multicolumn{1}{|c|}{ Source } & Lactose $\%$ \\
\hline Goat milk & $4.1 \%$ \\
\hline Sheep milk & $4.6 \%$ \\
\hline Cow milk & $4.6 \%-5.1 \%$ \\
\hline Bison milk & $5.7 \%$ \\
\hline Human milk & $6.9 \%$ \\
\hline $\begin{array}{l}\text { Table derived from Handbook of Milk of Non-Bovine Mammals } \\
\text { (Park, Haenlein, and Wendorff 2017). }\end{array}$ \\
\hline
\end{tabular}

Table 2. Amount of lactose in popular dairy products.

\begin{tabular}{|l|c|c|}
\hline \multicolumn{1}{|c|}{ Product } & Measure & $\begin{array}{c}\text { Lactose (g) } \\
\text { per Measure }\end{array}$ \\
\hline Eggnog & 1 cup & 19.9 \\
\hline Cow's milk (2\%, 1\%, skim, whole) & 1 cup & $12.2-12.7$ \\
\hline Hot chocolate & 1 cup & 11.6 \\
\hline Chocolate milk & 1 cup & 9.6 \\
\hline Cream of mushroom Soup & 1 cup & 7.0 \\
\hline Greek yogurt & 7 oz (1 container) & 5.8 \\
\hline Cottage cheese & 4 oz & 4.4 \\
\hline Whipped cream & 2 tbsp & 0.4 \\
\hline American cheese & 2 oz (1 slice) & 1.2 \\
\hline Cream cheese & 1 tbsp & 0.9 \\
\hline Mozzarella cheese & 1 oz & 0.3 \\
\hline Vanilla wafers & 8 wafers & 0.2 \\
\hline Cheddar cheese & 1 oz & $<0.1$ \\
\hline Ranch dressing & 1 tbsp & $<0.1$ \\
\hline Table derived from USDA National Nutrient Database for Standard \\
\hline Reference (2018). & & \\
\hline
\end{tabular}

\section{What should I do if I think I have lactose intolerance?}

Anyone who suspects lactose intolerance should seek a health professional opinion. True lactose intolerance is difficult to diagnose, and perceived problems could be the result of another underlying condition. For those diagnosed with lactose intolerance, treatments such as lactase supplements or probiotics may aid in the digestion of lactose (Oak and Jha 2018). Eliminating dairy products from the diet should not be recommended, as dairy foods provide beneficial nutrients. Eliminating dairy foods could lead to the development of other health issues, such as poor bone health. Replacing lactose-containing foods with brands low in lactose is recommended. People diagnosed with lactose intolerance may be able to eat a single serving of food with about 12 grams of lactose with few to no side effects (Misselwitz et al. 2013; Di Rienzo et al. 2013).

Table 2 highlights the amount of lactose found in popular dairy products. Consumers affected with lactose intolerance should monitor the dosages of lactose-containing products they consume. Other commercial products, such as processed meats (e.g., hot dogs and sausages) may contain dairy ingredients to improve texture or improve waterholding capacity. These products could serve as a hidden source of lactose; however, the amount present is low, so it is unlikely to induce lactose intolerance side effects.

In summary, individuals who suffer from lactose maldigestion may develop the negative side effects of lactose intolerance after consumption of lactose-containing products. If lactose intolerance is suspected, it is important to monitor the situation and to seek health professional advice to determine if the cause is truly lactose intolerance and its severity. Small doses of lactose-containing products may cause few or no symptoms in the lactose intolerant population. If lactose-containing product intake is completely excluded, it may be necessary to supplement the diet to reduce the risk of developing other health issues. With proper attention and management, lactose intolerant people should be able to reduce or avoid any negative side effects.

\section{References}

Di Rienzo, T., G. D’Angelo, F. D’Aversa, M.C. Campanele, V. Cesario, M. Montalto, A. Gasbarrini, and V.

Ojetti. 2013. "Lactose intolerance: from diagnosis to correct management." Eur Rev Med Pharmaco. 17: 18-25. 
Itan, Y., B. L. Jones, C. J. E. Ingram, D. M. Swallow, and M. G. Thomas. 2010. "A worldwide correlation of lactase persistence phenotype and genotypes." BMC Evol Biol. 10: 36.

Lomer, M. C. E., G. C. Parkes, and J. D. Sanderson. 2007. "Review article: lactose intolerance in clinical

practice - myths and realities." Aliment Pharmcol Ther. 27: 93-103

Misselwitz, B., D. Pohl, H. Fruhauf, M. Fried, S. R. Vavicka, and M. Fox. 2013. "Lactose malabsorption and

intolerance: pathogenesis, diagnosis and treatment." United Eur Gastroent. 1: 151-159.

Nicklas, T. A., H. Qu, S. O. Hughes, M. He, S. E. Wagner, H. R. Foushee, and R. M. Shewchuk. 2011. "Self-

perceived lactose intolerance results in lower intakes of calcium and dairy foods and is associated with hypertension and diabetes in adults." Am J Clin Nutr. 94: 191-198.

Oak, S. J., and R. Jha. 2018. "The effects of probiotics in lactose intolerance: A systematic review." Crit Rev Food Sci. 9: $1-9$

Park, Y. W., G. F. W. Haenlein, and W. L. Wendorff. 2017. "Overview of Milk of Non-Bovine Mammals," p. 11-20. In Handbook of Milk of Non-Bovine Mammals, $2^{\text {nd }}$ ed. Oxford, UK: Blackwell Publishing.

Scrimshaw, N. S., and E. B. Murray. 1988. "The acceptability of milk and milk products in populations with a high prevalence of lactose intolerance." Am J Clin Nutr. 48: 1142-1159.

Storhaug, C. L., S. K. Fosse, and L. T. Fadnes. 2017. "Country, regional, and global estimates for lactose

malabsorption in adults: a systematic review and metaanalysis." Lancet Gastroenterol Hepatol.

10: $738-746$.

United States Department of Agriculture (USDA). 2018. "USDA Food Composition Databases." https://ndb.nal. usda.gov/ndb/search/list 